\title{
JUVENILE SEX OFFENDER REHABILITATION: HOW THE US APPROACH CAN HELP INDONESIA SATISFY ITS COMMITMENT TO RESTORATIVE JUSTICE PRINCIPLES
}

\author{
Putri Kusuma Amanda*
}

\begin{abstract}
In July 2012, Indonesia enacted landmark legislation to reform the juvenile justice system. The Juvenile Justice Act is a break through which constituted to protect the rights of children in the juvenile justice system. This Act explicitly includes the principle of restorative justice, a principle that guarantees the government's commitment to use rehabilitative and restorative approaches. The question that arises now is how this law can be satisfied through the implementation of the Act. Specifically, this paper will focus on how the restorative justice principle can be applied to juvenile commit sexual offense. This paper, learning from the United State's rehabilitation system, will offer some suggestions to form the rehabilitation process for juvenile sex offenders in Indonesia, such as enhancing research about juveniles commit sexual offense; improving the law and regulation; and implementing counseling, supervised group homes, and other support mechanisms.
\end{abstract}

Keywords: Juvenile Justice, Sexual Offense, Restorative Justice, Rehabilitation, Child Protection

\begin{abstract}
Abstrak
Pada bulan Juli 2012, Indonesia memberlakukan undang-undang yang penting untuk mereformasi sistem peradilan anak. Undang-Undang Pengadilan Anak merupakan terobosan yang dibentuk untuk melindungi hak-hak anak dalam sistem peradilan anak. Undang-Undang ini secara eksplisit memasukkan prinsip keadilan restoratif, prinsip yang menjamin komitmen pemerintah untuk menggunakan pendekatan rehabilitatif dan restoratif. Pertanyaan yang muncul sekarang adalah bagaimana hukum ini dapat dipenuhi melalui penerapan Undang-Undang. Secara khusus, tulisan ini akan berfokus pada bagaimana prinsip keadilan restoratif dapat diterapkan terhadap remaja yang melakukan pelanggaran seksual. Tulisan ini, belajar dari sistem rehabilitasi Negara Amerika Serikat, akan menawarkan beberapa saran untuk membentuk proses rehabilitasi bagi pelaku remaja pelanggaran seksual di Indonesia, seperti meningkatkan penelitian mengenai remaja yang melakukan pelanggaran seksual; meningkatkan hukum dan peraturan; melaksanakan konseling, kelompok rumah yang diawasi, dan mekanisme pendukung lainnya.
\end{abstract}

Kata Kunci: Pengadilan Anak, Pelanggaran Seksual, Keadilan Restoratif, Rehabilitasi, Perlindungan Anak

Assistant Lecturer in Criminal Law Department University of Indonesia since 2011. Obtained Bachelor of Law from Universitas Indonesia (2010) and Master of Law (LL.M) from University of Washington (2013). Correspendence to putrik.amanda@gmail.com 


\section{Introduction}

Heartbreaking news arose in Makassar, Indonesia, as five fifth grader minors got arrested after raping a girl that was also their fifth grader classmate. ${ }^{1}$ This case, which happened recently in April 2013, was a shocking moment for our country not only because of the nature of the offense and the age of the victim, but also because of the offenders' age. Heading south from Makassar, on March 2013 in Jakarta, a group of thirteen teenagers were arrested for raping a fifteen year-old girl. ${ }^{2}$ In another case, a 17 -year old village boy raped his 15 year-old sister in their home while their parents were working in the field. ${ }^{3}$ The sister then became pregnant. ${ }^{4}$ These three cases were only few of many other sexual offenses committed by children that were brought into the criminal justice system. Based on the January 2011 data, $8 \%$ of the 5,421 cases of children in conflict with the law were sexual offense cases. ${ }^{5}$ While this is a low percentage, it is still considered the second most common offense committed by children following $53 \%$ cases of theft. ${ }^{6}$

Lack of parental control, psychological disorder, or history of abuse is considered to be some of the factor that can lead to a child's deviant sexual behaviour. ${ }^{7}$ Adrianus Meliala, a criminologist from University of Indonesia, suggests that juveniles commit sexual offenses because of the high intensity of watching and accessing pornography. ${ }^{8}$ Any of these backgrounds could have influenced the offenders discussed above. According to media reports, those children were firstly motivated because of the high intensity of watching pornography from their cell phones ${ }^{9}$ and because of the lack of parental control, their watching habit causes them to copy such actions to an actual person. ${ }^{10}$ From these explanations, we may conclude two basic causes that can

1 Bocah SD Pemerkosa Dipindahkan ke Dinsos Makassar [Elementary School Boys were Brought to Sosial Institution Makassar], LiputanChampions.com, http://www.liputanchampions.com/ video/1129644/5-bocah-sd-pemerkosa-dipindahkan-ke-dinsos-makassar (last visited April 23, 2013).

2 KPAI: Pemerkosaan dan Moralitas [KPAI: Rape and Morality], Kompas.com, http://megapolitan.kompas.com/read/2013/03/18/15035990/KPAI.Pelaku.Pemerkosaan.Bergilir.Biadab.dan.Tidak.Bermoral (last visited May 21, 2013).

3 Perkosaan Kakak-Adik [Sibline Rapes], SindoNews.com, http://daerah.sindonews.com/ read/2012/10/19/25/681193/sering-nonton-video-porno-kakak-perkosa-adik (last visited April 23, 2013).

4 Ibid.

${ }^{5}$ Indonesian Ministry of Women and Child Protection \& National Statistic Center (Menneg PPPA \& NSC), Profil Anak Indonesia 2011 [Profile of Children in Indonesia 2011] 78 (2011).

${ }^{6}$ The range of percentage between theft and sexual offense remains high. Id.

7 Yulina Eva Riany, Kekerasan Seksual dan Pornografi Pada Anak [Child Sexual Abuse and Pornography], Viva.co.id, http://us.analisis.news.viva.co.id/news/read/404620-kekerasan-seksual-dan-pornografi-pada-anak (last visited April 25, 2013).

${ }^{8}$ Geng Anak Pemerkosa [Child Rape Gangs], Republika.co.id, http://www.republika.co.id/berita/ nasional/jabodetabek-nasional/13/04/07/mkviiv-kriminolog-geng-anak-pemerkosa-karena-pornografi (last visited April 23, 2013). (As a result, they were urged to copy the same sexual contact to other person. Furthermore, international researches also shows how children's access to pornography may lead to aggressive sexual behavior. Lastly, in the case of juvenile sex offenders, a research found that twenty-nine out of thirty juvenile sex offenders had been exposed to pornography as a child and the average age of first exposure was about seven-and-a-half years). See Mary Eberstadt and Mary Anne Layden, The Social Costs of Pornography: A Statement of Findings and Recommendations 27 (2010).

${ }^{9}$ Bocah SD, supra note 1 .

${ }^{10}$ Ibid. 
lead children commit sex offenses: they were contaminated by pornography ${ }^{11}$ or they could have had a traumatic event ${ }^{12}$.

Putting these children in prison without any rehabilitative treatment will not help to solve the problem, nor even change the child's behavior. Life in the prison can estrange or isolate the children from society, causing less ability for the child to reintegrate to the society. ${ }^{13}$ Based on United States' report, although the recidivism rate of juveniles adjudicated of sex offenses is low, juveniles who become recidivist will likely to offend other delinquent behaviour (8-58 \%) rather than sex offenses $(5-14 \%) .{ }^{14}$ This situation is caused by the lack of rehabilitation and education program that were held in the prison. Therefore, instead of being educated and receiving treatment, child inmates, including the one who were adjudicated for sexual offenses, will learn to be criminals from other child or adult inmates..$^{15}$ This situation may be worsened with the increasing number of violence that happened inside the prison, both from prison guards and from older or stronger inmates. ${ }^{16}$

These problems in the criminal justice system do not help juveniles committed for sexual offenses to control their sexual behaviour. This situation contradicts the goal of Indonesia's juvenile justice system: to prepare the children to reintegrate to the society. ${ }^{17}$ One of the principles that were included in Indonesia's juvenile justice act is restorative justice that tries to increase the child offender's responsibility, increase the victim and community participation, and reduce the number of children being incarcerated in the detention centre ${ }^{18}$. To this extent, it is clear that the implementation of Indonesia's juvenile justice law is not fulfilled. Children who commit crimes are still victimized, and children that were adjudicated for sex offenses have not received the rehabilitation treatment that they need.

In contrast, the United States has modelled a more effective way to deal with juveniles. While the U.S. started their very first juvenile court with the

${ }^{11}$ Eberstadt, supra note 8, at 28.

12 Riany, supra note 7. see James RP Olgoff, et.al. Child Sexual Abuse and Subsequent Offending and Victimisation: A 45 Year Follow-up Study 1 (2012), available at http://www.casa.org.au/assets/ReportsPapers/Cutajar-offending-revictim-in-CSA-2012.pdf . ("Child Sexual Abused victims were almost five times more likely than the general population to be charged with any offense than their non-abused counterparts, with strongest associations found for sexual and violent offenses. Child Sexual Abused victims were also more likely to have been victims of crime, particularly crimes of a sexual or violent nature.")

${ }^{13}$ Martin Moerings, Apakah Pidana Penjara Efektif [Is Imprisonment Effective], in Hukum Pidana Dalam Perspektif [Criminal Law in Perspective] 235 (Topo Santoso ed., 2012).

14 National Center on Sexual Behavior of Youth (NCSBY), Review of Research on Adolescent Sex Offenders 1(2003), available at http://www.dshs.wa.gov/pdf/ca/NCSBYfactsheet.pdf. See also James Worling and Niklas Langstrom, Risk of Sexual Recidivism in Adolescents Who Offend Sexually: Correlates and Assessment, in The Juvenile Sex Offender 220-225 (Howard E. Barbaree, ed., 2006). It is hard to find similar data in Indonesia.

${ }^{15}$ Elfina L. Sahetapy, Restorative Justice dalam Wujud Diversi: Kasus Anak yang Berkonflik dengan Hukum [Restorative Justice and Child in Conflict with Law, in Hukum Pidana Dalam Perspektif [Criminal Law in Perspective] 300-301 (Topo Santoso ed., 2012).

${ }^{16}$ See Pusat Kajian Perlindungan Anak (PusKaPA) [Center of Child Protection Studies (PusKaPA)], Mekanisme Pembinaan, Rehabilitasi, dan Reintegrasi Sosial bagi Anak di Indonesia [Development, Rehabilitation, and Social Reintegration Mechanism for Children in Indonesia] 1-3 (2012).

${ }_{17}$ Undang-Undang Sistem Peradilan Pidana Anak 11/2012 [Juvenile Justice Act], introduction (Indon.).

\footnotetext{
18 Sahetapy, Id.
} 
spirit of rehabilitation, ${ }^{19}$ it ended up with harsher punishment for juveniles in the last two decades. ${ }^{20}$ In fact, for serious offenses, juveniles can be locked-up for more than twenty years; they can even be transferred to adult criminal court and be treated as adults. ${ }^{21}$ But, at the same time, juveniles in the juvenile detention center in the U.S. received a better facility and treatment than in Indonesia. In terms of juvenile that commit sex offenses, along with an advanced quality of research, rehabilitative treatment has been a part of handling them. ${ }^{22}$ Some treatment even has a restorative approach that does involve three important parties in the criminal justice system: the offender, the victim, and the society. ${ }^{23}$

By looking at the rehabilitative system applied in the U.S., Indonesian government should learn from the U.S. as a starting point to prove its commitment to their juvenile justice system. However, challenges and barriers may be faced in the future based on Indonesia's own characteristic and culture. Implementing restorative justice principle is not easy, and rehabilitating juvenile sex offenders with restorative justice approach is even harder. Therefore, it is important to have a well planned strategies and cooperation between stakeholders to overcome the challenges.

This paper will describe how Indonesia's juvenile justice system handles juveniles accused of sexual offenses. It will also illustrate how the overlapping laws in Indonesia create confusion in handling sexual offense cases committed by juveniles. Then, it will discuss the legal, institutional, and community barriers that Indonesia will face when it implements rehabilitation for juvenile commit sexual offense. Finally, learning from the United State's rehabilitation system, this paper will offer some suggestions to form the rehabilitation process for juvenile sex offenders in Indonesia, such as enhancing research about juveniles commit sexual offense; improving the law and regulation; and implementing counseling, supervised group homes, and other support mechanisms.

\section{Handling Juvenile Sex Offenders Under the Indonesian Legal System}

Under the Indonesian legal system, two basic laws will apply to children who commit criminal offenses. The first law is material or substantive laws regulating their offense and the sanctions. ${ }^{24}$ For sexual offenses, the regulation varies and spread into different laws. The laws are differentiated

${ }^{19}$ Howard W. Snyder \& Melissa Sickmund, Nationall Center for Juvenile Justice, Juvenile Offenders and Victims: 1999 National Report 86-87 (1999)

${ }^{20}$ Jeffrey K. Day, Juvenile Justice in Washington: A Punitive System in Need of Rehabilitation, 16 U. Puget Sound L. Rev. 400 (1992)

${ }^{21}$ Donna M. Bishop, Juvenile Offenders in the Adult Criminal Justice System, 27 Crime \& Just. 81, 94-100 (2000)

${ }^{22}$ see Gary O'Reilly and Alan Carr, Assessment and Treatment of Criminogenic Needs, in Juvenile Sex Offender 190-93 (2006).

${ }^{23}$ Mary P. Koss, et al. Disposition and Treatment of Juvenile Sex Offenders from the Perspecitve of Restorative Justice, in Juvenile Sex Offenders, 348-51 (2006).

${ }^{24}$ The laws varies depends on the act that they commit. The basic law is Indonesian Criminal Code Code 1946. Kitab Undang-Undang Hukum Pidana 1946 [KUHP][Crim Code] (Indon.) 
by the character of victims that will affect the harshness of the sanction. The more specific the victim is, the harsher the sanction will be. For example, if the victim is a child, then the offender can be sentenced to 15 years under the Child Protection Act. ${ }^{25}$ If the victim is part of the nuclear family with the offender, then Domestic Violence Act can be applied with imprisonment of 15 years. $^{26}$

The second law that will apply to the children is the Juvenile Justice Act. The Juvenile Justice Act itself is still a new law that is enacted on July 2012 overruling the old Juvenile Court Act of 1997. ${ }^{27}$ The Juvenile Justice Act law regulates procedures and converted sanctions that will apply to juveniles in the criminal justice system. Based on this Act, the maximum sanctions for juveniles is half from maximum sanctions applied to adults. Therefore, the punishment will be lesser than the default sanction in the material laws. ${ }^{28}$

\section{A. Defining Sex Offenses: Confusion Under Variety of Laws}

Sex offenses under the Indonesian regulation were divided into two categories: rape (pemerkosaan) and molestation (pencabulan). As mentioned, the differences among the laws are based on the character of the victim that will impact the maximum sanction. Harsher sanctions are usually regulated when the victim is a child. This may lead to confusion when law enforcement officers have to deal with juveniles who commit sexual offenses, especially when most of the victims are also children. In one side the law is harsher because the victim is a child, in the other side, the special law with lighter sanction should be applied because the offender is also a child.

\section{Sex Offenses Under the Indonesian Penal Code}

Indonesian Penal Code, known as Kitab Undang-Undang Hukum Pidana / KUHP, is the main regulation that governs certain offenses in Indonesia's criminal law system. ${ }^{29}$ The penal code itself is a product of Dutch colonialism and has been applied since $1946 .{ }^{30}$ Currently, the revision of this code is being discussed in the House of Representative. ${ }^{31}$

The Penal Code regulates 11 articles related to rape (5 articles) and molestation ( 6 articles) with the range of maximum sentences between 4 to 15 years of imprisonment. Considering that the Code is a product of colonialism, this classification is based on a very traditional and outdated perspective. Raping a boy is not considered as rape under this law; instead, it

\footnotetext{
${ }^{25}$ Undang-Undang Perlindungan Anak 23/2002 [Child Protection Act] art. 77-90 (Indon.)

26 Undang-Undang Penghapusan Kekerasan Dalam Rumah Tangga 23/2004 [Domestic Violence Act] art. $44-49$ (Indon.)

${ }^{27}$ Id. art. 106.

${ }^{28}$ See Juvenile Justice Act chapter 5 (Indon.)

${ }_{29}$ Muladi, Beberapa Catatan Terhadap RUU KUHP (Several Notes about the Draft Revised Penal Code) in Beberapa Tulisan Terkait Kebijakan Kriminal dalam RUU KUHP (Notes Related to Criminal Policy in the Penal Code Draft) 8-10 (ELSAM, 2006).

30 Ibid.

31 The penal code is outdated and there is a need to reform it based on the current development of law in Indonesia. Ibid.
} 
is considered as molestation. The most severe sanction is if the act of sexual offenses causes death (maximum 15 years of imprisonment). ${ }^{32}$ Furthermore, the second severe sanction is if the victim of the offense is woman (maximum 12 years of imprisonment). ${ }^{33}$ If the victim is a child, the penal code regulates it in 5 different articles: child (women) rape with maximum of 9 years, ${ }^{34}$ child marriage with maximum of 4 years ${ }^{35}$, child molestation with maximum of 7 years, ${ }^{36}$ same sex child molestation with maximum of 5 years, ${ }^{37}$ and rape to a child under a nuclear family relationship with maximum of 7 years imprisonment. ${ }^{38}$

\section{Sex Offenses under the Child Protection Act}

Child Protection Act is a regulation that governs certain supporting system to fulfil the child's rights in Indonesia. ${ }^{39}$ It is established as a guarantee to protect the child's needs in every aspect so that a child can live and grow with prosperity. ${ }^{40}$ The Act also exists to strengthen the government's commitment to protect child of Indonesia from violence and discrimination. ${ }^{41}$ As a part of this commitment, the government added specific articles which regulate harsher punishment for any violations against a child, including sexual offenses ${ }^{42}$.

There are two articles that are related to sexual offense: child rape ${ }^{43}$ and child molestation ${ }^{44}$. Unlike the Criminal Code, this Act does not distinct the victim's gender. Therefore, as long as the victim is a child, pertains to any person under 18 years old, then this law could be applied. Maximum sentence for both offenses are 15 years of imprisonment and fine between 60 million to 300 million Rupiah (average to $\$ 6,000-\$ 30,000) .{ }^{45}$ This article is where the dilemma between child offender and child victim starts.

As mentioned previously, Child Protection Act exists to protect a child in any situation. Therefore, children in the situation in conflict with law were also the object of protection. ${ }^{46}$ In this law, a child with conflict with the law should have a special protection in the criminal justice system and should receive measurable and reasonable sanctions based on the interest of a child. ${ }^{47}$ On the other hand, the law gives harsher punishment for any acts that victimized

\footnotetext{
${ }^{32}$ Crim. Code art 288 (3) (Indon.)

33 Ibid., art 285.

${ }^{34}$ Ibid., art 287 (1).

35 Ibid., art 288 (1).

36 Ibid., art 290 (2).

37 Ibid., art 292.

38 Ibid., art 294.

${ }^{39}$ Child Protection Act, introduction (Indon.)

${ }^{40}$ Ibid., art. 3.

${ }^{41}$ Ibid.

42 Ibid. article $81 \& 82$.

43 Ibid. article 81

${ }^{44}$ Ibid. article 82

${ }^{45}$ Ibid. article 81 \& 82

${ }^{46}$ Ibid. article 64

47 Ibid. article 64 (2)
} 
a child. ${ }^{48}$ In the case of sexual offense by a child, they will find victim that is weaker than them, thus the victim will also be children as it shown in the three cases that were mentioned previously. Therefore, the Child Protection Act is a strength and also barrier in the same time when dealing with children who victimized children.

3. Sex Offenses Under The Domestic Violence Eradication Act (Domestic Violence Act)

Sex offenses regulation in this law is focused on the family relationship between the offender and the victim. Sentence for rape to a person in the household is maximum 12 years of imprisonment, or maximum fine of 36 million Rupiah (about \$3,600.00). ${ }^{49}$ Under this regulation, a juvenile will be charged if they victimized their own siblings or any other person in the household.

Indonesian Criminal Code, Child Protection Act, and Domestic Violence Act are three law that regulates sanctions for a person accused for sex offenses. In the case of juvenile, if the victim is also a child, then Child Protection Act could be applied. Furthermore, if the victim has a family relationship with the offender, then Domestic Violence Act could be applied. Although these two laws established to protect children, it didn't consider the situation if the offender were also children.

In practice, if there is a crime committed, police officers will start investigation and draft a report known as "BAP".50 During the process of investigation, a police officer will coordinate with the prosecutor to decide what law that will be applied to the offender. ${ }^{51}$ The prosecutor then will analyze the BAP and if they see that the BAP is unclear or haven't met the elements of the article charged, the prosecutor then could return the BAP to the police officer to be revised. ${ }^{52}$ Furthermore, if the BAP is ready, the prosecutor will then draft the indictment and bring the case to the court. ${ }^{53}$ Judges will have to decide based on the prosecutor's indictment. Therefore, in the criminal procedural law, police officers along with prosecutors have an important role to decide which article that will be charged for all criminal cases.

Based on the explanation above, children accused of sex offenses could be charged with a harsher punishment either under the Child Protection Act or the Domestic Violence Act. As an addition, although there are three laws that could be applied for juveniles, in the end, the sanctions will be converted under the regulation in the Juvenile Justice Act. However, the Juvenile Justice Act also gives other types sanctions as an alternative of imprisonment, including diversion and treatment. Therefore, the Juvenile Justice Act plays a big role in opening the chance for juveniles to receive rehabilitation.

${ }^{48}$ Ibid. Chapter XII.

49 Domestic Violence Act art. 46 (Indon.). The law doesn't regulate any sanction for molestation acts. The Domestic Violence Act only define sexual violence as any act that enforces a person in the household to have a sexual contact with the offender or other person.

${ }^{50}$ Kitab Undang-Undang Hukum Acara Pidana 8/1981 [Crim.Pro.Code]art 110 (1) (Indon.).

${ }^{51}$ Ibid., art 110 (1)

${ }^{52}$ Ibid., art 110 (2), 110 (3), 138 (1), 138 (2).

${ }^{53}$ Ibid. art 139 


\section{B. Juvenile Justice Act: Guidance of the Criminal Procedural Law for Juvenile Offenders}

In 2012, the Indonesian legislature enacted the new Juvenile Justice Act that replaced the old juvenile justice law named "The Juvenile Court Act" (No. 3/1997). It replaced the old law because the previous one didn't comprehensively give protection to a child in conflict with the law. ${ }^{54}$ Unlike the old law, the Juvenile Justice Act explicitly stated its basic principle based on protection, just, non-discrimination, best interest of the child, respecting the child's voice, proportionality, and non-punitive. ${ }^{55}$ The law also protects the rights of the child to be treated differently than adults, to receive legal assistance, rights to be protected from publicity, rights to education and healthcare. ${ }^{56}$

This law limits juvenile's criminal responsibility in the age between twelve to eighteen. ${ }^{57}$ Therefore, juvenile criminal offenders under twelve years old should not be processed in the criminal justice system. The increased age limitation for criminal responsibility was promulgated to prevent underage children from being brought to the criminal justice system..$^{58}$ Furthermore, the new law also limits juvenile aged between 12 to 14 years old so that they can only be sentenced with alternative sanctions. ${ }^{59}$

The new Juvenile Justice Act also explicitly states its commitment in restorative justice that becomes a key to implement diversion, which has the goal to form a restorative approach between the offender and victim. This process will result in any outcome that prevents the child from entering in the traditional criminal justice system, avoid a child being incarcerated in the detention centres, increase society's awareness and participation, and increase the child's responsibility. ${ }^{60}$ The process of diversion is required in every steps of the criminal procedural law. ${ }^{61}$ Therefore, police officers, prosecutors, and judges have to promote diversion process in every step of the criminal justice system. If the diversion process didn't run well in the police's office, diversion should also be repeated in the prosecutor's office, and last in front of the judge. The diversion procedure will run through conference that involves offender, victim (if possible), both parents of the offender and victim, pembimbing kemasyarakatan (that assessed the juvenile's personality, family, and community background), social worker, ${ }^{62}$ and the community. ${ }^{63}$ The result of diversion can be retribution, rehabilitation, being returned to the offender's parents, involvement in the institutionalized treatment for a

\footnotetext{
${ }^{54}$ Juvenile Justice Act, introduction, (Indon.).Introduction of the Juvenile Justice Act 11/2012.

55 Ibid. art 2.

56 Ibid. art 3.

${ }^{57}$ Ibid. art 1 (3). Although it defines juvenile between those age, the law also stated sanctions that applied to juveniles under the age of twelve. This law somehow is a paradox. See Id. art. 69 (2).

58 One phenomenal case is the 8-year-old Raju Case in 2006. He was tried for assault stemming from a fight with a schoolmate. See Indonesia Gets Failing Grade Juvenile Justice System, TheJakartaPost. com, http://www.thejakartapost.com/news/2007/07/28/indonesia-gets-failing-grade-juvenile-justicesystem.html (last visited May 29th, 2013).

${ }^{59}$ Juvenile Justice Act art. 69 (Indon.)

${ }^{60}$ Ibid., art. 6.

${ }^{61}$ Ibid., art.7.

${ }^{62}$ Ibid.

63 Ibid.
} 
maximum of 3 months, or community service for a maximum of 3 months. ${ }^{64}$

Although the existence of diversion may be a good relief for the future of Indonesia's juvenile justice system, the process of diversion is limited to violations of law that have a maximum sentence of 7 years and are not recidivism. ${ }^{65}$ A child who commits a more serious crime, including sexual offenses, might not have a chance to be involved in the diversion process because the maximum sentence for sexual offense is 12 to 15years. Nevertheless, this article is also vague. It is not clear whether the 7years maximum sentence is based on the adult maximum sentencing or juvenile maximum sentencing.

Article 81 paragraph 2 of the law stated that the maximum sentencing for a child is $1 / 2$ of the maximum sentencing for adults. ${ }^{66}$ If the requirement for diversion is based on the adult standard, then there is no chance for juveniles who commit sexual offenses to have diversion; and if the requirement is based on the juvenile standard, then the only law related to sexual offense that can be applied for diversion is the Domestic Violence Act.

Some of the differences between the new law and the prior law include variety of criminal sanctions. Furthermore, the new law also provides rights for the victims to rehabilitation, mental and physical health, and information about the progress of the criminal case. ${ }^{67}$

\section{III.Child's Rights, Restorative Justice and Rehabilitative Approach: Justifications to Provide Rehabilitation for Children Who Have Sexually Offended}

"Budi" was a sixteen year old boy when he was caught because of a crime that he did not commit. He was charged with theft and was incarcerated for five months. ${ }^{68}$ Budi didn't remember how long the process was from the time he was arrested, to the time he was interrogated by the police, or was brought to the prosecutor, then tried in the court. What he remembered is that the process was long and often delayed. Budi stated that he was physically abused when interrogated by the police. During the time waiting for his trial, Budi was brought to custody and detained with adults. Then, when Budi was incarcerated in the juvenile detention centre, he saw how the officers treated the inmates without respect. He was even asked by the officer to pay them so that all his process would run 'smoothly' or he could get lighter sanction.

Not all juvenile detention centres in Indonesia are separated from adult facilities. ${ }^{69}$ In fact, due to the lack of facilities, some children are only separated from adult cells. ${ }^{70}$ In this case, Budi was brought in the juvenile

64 Ibid., art. 10

65 Ibid., art. 7.

66 Ibid., art. 81.

${ }^{67}$ Ibid., art. 90.

${ }^{68}$ This story is based on the report from Centre of Child Protection Studies, University of Indonesia. See PusKaPa, supra note 16 at xi.

${ }^{69}$ Id.

70 Kementerian Pemberdayaan Perempuan dan Perlindungan Anak [Menneg PP\&PA][Ministry of Women and Child Protection], Child Conflict with The Law" (2011). Available at http://menegpp.go.id/V2/ index.php/datadaninformasi/perlindungan-anak 
detention centre that is in the same building with adults. Budi still had contact with adult inmates and during that time, he could see a lot of violation that happened in the detention centre.

The story of Budi is only one of many stories that are even worse. ${ }^{71}$ Budi's story shows how the criminal justice system in Indonesia treats the children, whether they are wrongfully convicted or convicted of a sex offense, and how much it violates the rights of the children. In the reality of juvenile justice system, the practice tends to give a traumatized experience instead of providing a safe and rehabilitative environment to the children. ${ }^{72}$ In addition, children that have finished their prison time are released without having prepared but to have more experience in violence, not to mention that they will also be labelled as criminal, and being re-victimized by the community. ${ }^{73}$

The story of Budi shows that the Indonesian Juvenile Justice System has not give individualized treatment to children. All children are treated without any measures to define what special treatment that each child needs. As a result, a teenager like Budi, five fifth grader children, a sibling charged with rape, and children charged with gang rape will be brought into the criminal justice system and will be put in prison, and they will not receive the special treatment that they need.

The current situation is contradictive with the spirit of Indonesia's Juvenile Justice Act 2012 that emphasizes the principle of restorative justice, rehabilitation, and reintegration. Whereas these principles are also included as a part of Indonesia's commitment to implement rehabilitation principles from international laws, including the United Nations Convention on The Rights of The Child.

\section{A. Commitment of the United Nations Convention on the Rights of The Child (UNCRC)}

In 1990, Indonesia joined other countries to ratify the Convention on the Rights of the Child ("UNCRC"). ${ }^{74}$ This convention is the first legally binding international instrument to incorporate the full range of human rights of a child. ${ }^{75}$ It sets out the rights in 54 articles and two Optional Protocols. ${ }^{76}$ It spells out the basic human rights that children everywhere should have, including children that were brought in the criminal justice system. ${ }^{77}$ By agreeing to

${ }^{71}$ According to the National Commission of Child Protection 2010 Report, there were 1,851 cases that reports to them for an abuse against children in the criminal justice system. Komisi Nasional Perlindungan Anak [KomnasPA] [National Commission of Child Protection], Database Pelanggaran Hak Anak di Indonesia 2010 (Child's Rights Violation 2010 Database) 2 (2010).

${ }^{72}$ PusKaPa, supra note 16.

${ }^{73}$ Paulus Hadisuprapto, Peradilan Restoratif: Model Alternatif Perlindungan Hukum Anak dalam Perspektif Hukum Nasional dan Internasional (Restorative Court: Alternative Model to Protect a Child's Legal Rights in the National and International Perspective), in Hukum Pidana dalam Perspektif (Criminal Law in Perspective) 262 (Topo Santoso, ed., 2012).

${ }^{74}$ It is ratified under the Presidential Decision (Keputusan Presiden) 36/1990. Keputusan Presiden 36/1990 [Presidential Decision] (Indon.)

${ }^{75}$ Convention on the Rights of The Child [U.N. CRC], G.A. Res. 44/25, U.N. GAOR, 44th Sess., Supp. No. 49, U.N.Doc A/44/25 (Nov. 20, 1989).

76 Ibid.

77 Ibid. 
undertake the obligations of the Convention, Indonesians have committed themselves in protecting and ensuring children's rights.

Ratification of this convention leads Indonesia to develop and undertake all actions and policies in the light of the best interests of the child. ${ }^{78}$ The obligations that Indonesia has to take includes "taking all appropriate measures in dealing with a child alleged as, accused of, or recognized as having infringed in the penal code". ${ }^{79}$ In terms of sanction, Indonesia has a duty to take any appropriate measurement before giving a sanction to a child. Furthermore, imprisonment of a child shall be based by law and shall be used only as a measure of last resort and for the shortest appropriate period of time. ${ }^{80}$ The convention also stated a variety of dispositions to promote alternative sanctions for children in conflict with the law. The alternative sanctions include, but are not limited to, guidance and supervision orders; counselling; probation; foster care; education and vocational training program and other alternatives to institutional care. ${ }^{81}$

The convention also mentions the rights of child victim and urges state parties to take all appropriate measures to promote physical and psychological recovery and social reintegration of child victims of "any form of neglect, exploitation, or abuse; torture or any other form of cruel, inhuman or degrading treatment or punishment; or armed conflicts." ${ }^{2}$ Such recovery and reintegration shall take place in an environment which fosters the health, self-respect and dignity of the child. ${ }^{83}$

All juveniles who are in conflict with the law have a need to be rehabilitated. They did their actions with a limited capacity and may have been influenced by other factors. As explained earlier, juveniles who commit sexual offenses may have been influenced by pornographic media or traumatic events. ${ }^{84}$ Some of them may have been victims of sexual abuses themselves, which may have transformed them to have aggressive sexual behaviour. Nevertheless, treatments that have been applied in some other countries show that children that commit sexual offenses are amenable to rehabilitation ${ }^{85}$ and giving rehabilitation is more likely in the same light of the best interest of a child. Giving rehabilitation for juvenile who commits sex offenses is also consistent with the goals of the UNCRC.

${ }^{78}$ Ibid.
${ }^{79}$ Ibid. $\operatorname{art} 40$ paragraph 1.
${ }^{80}$ Ibid. $\operatorname{art} 37$ paragraph 2.
${ }^{81}$ Ibid. art 40 paragraph 4 . As an additional guidance, the comments of the UNCRC also stated that

81 Ibid. art 40 paragraph 4 . As an additional guidance, the comments of the UNCRC also stated that
in conflict with the law has the right to treatment which promotes the child's sense of dignity and a child in conflict with the law has the right to treatment which promotes the child's sense of dignity and
worth, takes the child's age into account and aims at his or her reintegration into society and avoid institutional placement wherever possible. See Childs Rights International Network, Conventions on the Rights of The Child: General Comments, http://www.crin.org/docs/resources/treaties/uncrc.asp\#Nine. Following the convention, UN also established a guideline for the Administration of Juvenile Justice (known as the Beijing Rules). This guidelines put rehabilitation and reintegration as their main principle and promotes alternative strategies to prevent children being incarcerated. PusKaPa, supra note 16 .

${ }^{82}$ U.N. CRC art 39.

83 Ibid.

${ }^{84}$ Riany, supra note 7.

85 Association for the Treatment of Sexual Abusers (ATSA), The Effective Legal Management of Juvenile Sex Offender (2000, March 11), available at http://www.atsa.com/ppjuvenile.html 


\section{B. Restorative Justice Principle}

Along with the spirit to give more rehabilitation to children in conflict with the law, one of the concepts that arise in the new Juvenile Justice Law in Indonesia is restorative justice. The concept itself is an alternative of the traditional criminal justice system that tends to give retributive and punitive effect in any criminal offenses. The aims of restorative justice are empowerment of victim, acceptance of responsibility of offenders, repair of harm strengthening the social bonds of victims and offenders to their community within the constraints of due process and proportionality ${ }^{86}$ This principle establishes that there should be a balance or parity among the victims, offenders, and the community. ${ }^{87}$

The involvement of the community in the restorative justice process is also transformative. ${ }^{88}$ The victim is validated and embraced. The offender is held accountable and supported in his or her transformation, and, if the necessary changes are made, he or she can be reintegrated into the community. ${ }^{89}$ The community is involved in healing the harm, and a sense of community is created where one may not have existed previously. ${ }^{90}$ Compared to traditional juvenile justice, restorative justice improves responsiveness for the victims, increases perceptions of fairness among all participants, and leads to better objective outcomes. Restorative justice methods may be implemented at any stage of the justice process, including pre-charging and post-conviction. ${ }^{91}$

In practice, there is no single method for achieving the goals of these principles. There are a number of variations and models that are developed. ${ }^{92}$ These models can include restitution, community service, victim support services, victim compensation programs, and rehabilitation programs for offenders ${ }^{93}$ All these varieties will require agreement from all parties concerned: the victim, the offender, and the community. ${ }^{94}$ Referring to such understanding, the handling of criminal cases through the restorative justice approach offers different views and outcomes in terms of understanding and dealing with a crime. ${ }^{95}$

Some countries have included this concept in their formal criminal

${ }^{86}$ Koss, supra note 23 , at 340 .

87 Ibid.

${ }^{88}$ Hon. T. Bennett Burkemper, Jr, et.al., Restorative Justice in Missouri's Juvenile Justice, 63 J. Mo. B. 128 (2007).

89 Ibid.

90 Ibid.

91 Koss, Ibid., at 336.

92 Eva Achjani, Restorative Justice in Indonesia: Traditional Value, 2 Indon. L. Rev. 3 (2011).

93 Daniel W. Van Ness \& Pat Nolan, Legislating for Restorative Justice, 10 Regent U.L.Rev. 53, 54 (998).

94 Paul Tullis, Can Forgiveness Play a Role in Restorative Justice?, N.Y.TIMES (January 4, 2013) available at http://www.nytimes.com/2013/01/06/magazine/can-forgiveness-play-a-role-in-criminaljustice.html?pagewanted=1\&_r=3\&comments.

95 Achjani, ibid. See also Mary Ellen Reimund, The Law and Restorative Justice: Friend or Foe? A Systemic Look at the Legal Issues in Restorative Justice, 53 Drake L. Rev. 667, 671 (2005). 
justice system ${ }^{96}$, such as Australia, ${ }^{97}$ Canada, ${ }^{98}$ Finland, ${ }^{99}$ Ghana, ${ }^{100}$ Bulgaria, ${ }^{101}$ and Belgium, ${ }^{102}$ by using mediation to re-open a criminal case even after the completion of the judicial system. In addition, there are some countries like the United Kingdom, ${ }^{103}$ New Zealand ${ }^{104}$ and South Africa, ${ }^{105}$ that included the restorative justice concept as a part of the prosecution system. ${ }^{106}$ In Indonesia, the restorative justice principle is mentioned in the Juvenile Justice Law but it has not yet to be put into practice in a realistic or effective way.

With the advent of this new law, the way of treating juveniles in Indonesian criminal justice system has theoretically evolved from a punitive approach to an offender-victim centred approach that tries to find a better solution to the causes of the crime. ${ }^{107}$ Furthermore, considering the loopholes that happened in the end of the criminal justice system which often incarcerated children, restorative justice could be the solution to overcome it. This restoring principle will be much more effective to deal with children who have committed sex offenses and need rehabilitation, rather than being in a non-rehabilitative environment in the prison.

Incorporating restorative justice in Indonesia's juvenile justice system can strengthen the rehabilitation approach for juvenile who commit sexual offenses. Involving community to find a progressive solution will increase the society's support, reduce stigmatization and will help the children to reintegrate and be a productive member of the society. ${ }^{108}$

\section{Rehabilitative Approach for Children Committing Sexual Offenses}

Based on the Indonesian Correctional Law No. 12/1995, the goal of correctional system is to prepare the inmates, especially children, to be reintegrated to the society and have productive and safe interactions with the society. These preparations should lead them to free, responsible, and productive members of the society. ${ }^{109}$ To implement this function in the correction system, the law established three units: custodial unit, correctional unit, and correctional hall. ${ }^{110}$ All these units are urged to develop the inmate's character, lead them to admit their mistakes, evaluate, change, and decide not

\footnotetext{
96 Achjani, Ibid.

${ }^{97}$ Crimes (Restorative Justice) Act 2004 (Canberra, Australia)

98 Youth Criminal Justice Act -2002(Canada)

${ }_{99}$ Act on Mediation in Criminal and Certain Civil Cases (Finland)

100 Children's Act 1998 (Ghana)

101 Law on Mediation. Prom. SG. 110/17 Dec 2004. (Bulgaria)

102 Law of 22 / 2005 on mediation (Belgium)

${ }_{103}$ Youth Justice and Criminal Evidence Act 1999 (UK)

104 Corrections Act 2004. (New Zealand)

105 Probation Servcies Amendment Act 2002. (Republic of South Africa)

106 Achjani, Ibid.

107 This process is not focusing on what should be done to the offender, thus it distinguishes it from punitive and rehabilitative approach. See Reimund, supra note 97, at 671.

${ }^{108}$ However, there need to be a further discussion to decide whether victim should also be involved in the application of restorative justice for sexual offenses. Incorporating victim of sexual offense is still debatable because of the nature of sexual offense that may cause serious trauma to the victim. Ibid.

${ }_{109}$ Undang-Undang Pemasyarakatan [Correctional Act] art. 3 (Indon.)

110 PusKaPa, supra note 16.
} 
to repeat their criminal behaviour. ${ }^{111}$

Once again, Indonesia has developed numerous laws that promote rehabilitation in the criminal justice system; therefore, rehabilitation for juveniles committing sexual offenses should also be implemented, especially since substantial research shows how juveniles are more successful when they received treatment. Although it is hard to find qualified research related to juvenile committing sexual offenses in Indonesia, the data that were found in the United States can be relieving news for the effort to implement rehabilitation for these children.

Rehabilitating juvenile sex offenders can prevent youths from committing sexual offenses as adults. ${ }^{112}$ Studies reveal that fifty percent of adult sex offenders committed sexual offenses as adolescents. ${ }^{113}$ Furthermore, the nature of much of juvenile sexual offending indicates that rehabilitation is possible. ${ }^{114}$

A study by Lorraine R. Reitzel and Joyce L. Carbonell in 2006 shows that rates of sexual recidivism is lower than rates of non-sexual recidivism. ${ }^{115}$ Therefore, there is a need to reduce the chance for put them in incarceration, because once they get into prison, they may not commit additional sex offenses, but they will get involved in the system in prison that leads them to do other crime. ${ }^{116}$ Furthermore, the research also shows that there was a statistically significant difference between sexual recidivism rates for those juvenile offenders receiving treatment versus those receiving no treatment. ${ }^{117}$

Again, the stated goal of the Indonesian justice system is for children to be rehabilitated and to help them become productive members of the society. Therefore, rehabilitation will help to achieve such goal and prevent recidivism, either sexual offenses or non-sexual offense.

\section{IV.The United States' Juvenile Justice System and Its Rehabilitative Approach to Juvenile Sex Offenders}

As mentioned in the introduction, the United States has their own way to deal with children in conflict with the law. The United States is not a state party that participates in ratifying the United Nations Convention on The Rights of The Child. ${ }^{118}$ Therefore, juvenile justice systems in the U.S. are based

111 Correctional Law art. 2. (Indon.)

112 Sander N. Rothchild, Beyond Incarceration: Juvenile Sex Offender Treatment Programs Offer Youths A Second Chance, 4 J.L. \& Pol'y 719, 727-30 (1996).

113 Ibid.

114 Ayn Embar Seddon \& Allan D. Pass, Assessing, Managing, and Treating Juvenile Sec Offenders, 2004 J. Inst. Just. Int'l Stud. 112 (2004)

115 Lorraine R. Retzel and Joyce R. Carbonell, The Effectiveness of Sexual Offender Treatment for Juveniles as Measured by Recidivism: A Meta-analysis, 18 Sex Abuse 401, 413 (2006), available at http:// www.wisspd.org/htm/ATPracGuides/Training/ProgMaterials/CH980-09/ESOTJ.pdf

116 Ibid.

117 Ibid.

118 The U.S. is the only state besides Somalia and South Sudan that hasn't ratify this convention. Benjamin Shmueli, The Influence of the United Nations Convention on the Rights of the Child on Corporal Punishment - A Comparative Study, 10 Or. Rev. Int'l L. 189, 236 (2008) [citing Michael Freeman, Introduction: Children as Persons, in Children's Rights: A Comparative Perspective 1 (Michael Freeman ed., 1996)]. 
on the laws and jurisprudence which has evolved since the first juvenile court was established in 1899.119

Originally, the juvenile justice system in the United States was established to emphasize rehabilitation with the belief that juveniles are capable to change with treatment. ${ }^{120}$ The underlying premise was the belief that children are malleable and are capable of being reformed. ${ }^{121}$ They were based on a legal doctrine called "parens patriae" (parent of the country), meaning that the court has a power to be the guardian of those who have legal disabilities, including juveniles. ${ }^{122}$ But then, in the late 1980's, the society found dissatisfaction in the practice of the juvenile system. The goal then shifted from rehabilitation to punitive approach for the protection of the public ${ }^{123}$ causing changes by treating more juvenile offenders as criminals. ${ }^{124}$ However, in recent years, the pendulum is swinging back as it tries to balance punitive approach into a more rehabilitative and less harsh proceedings. ${ }^{125}$

Rights of juveniles were guaranteed under the Supreme Courts decision of In re Gault. ${ }^{126}$ In its opinion, the majority stated that the Fourteenth Amandment, the Bill of Rights, and the due process of law should be applied to juvenile proceedings. ${ }^{127}$ This case changed the nature of juvenile court in the U.S. by giving children many of the same rights that adults have in criminal proceedings such as the right to notice of proceedings, ${ }^{128}$ the right to counsel, ${ }^{129}$ and the right to confront and cross examine witnesses. ${ }^{130}$ However, based on McKeiver v. Pennsylvania, the U.S. Supreme Court refused to extend

119 Treatment and Control Panel on Juvenile Crime, Juvenile Crime Juvenile Justice 157 (2001)

${ }^{120}$ J.V. Becker \& S.J. Hicks, Juvenile Sexual Offenders: Characteristics, Interventions, and Policy Issues 387-410 (2003)

${ }^{121}$ Kristin L. Caballero, comment, Blended Sentencing: A Good Idea for Juvenile Sex Offenders?, 19 St. John's J. 379, 384 (2005).

${ }^{122}$ Daniel E. Witte, comment, People v. Bennett: Analytic Approaches to Recognizing a Fundamental Parental Right Under the Ninth Amendment, 1996 BYU L. Rev 186, 227-34 (1996)

${ }^{123}$ Becker and Hicks, supra note 122. See also Caballero, supra note 123 (describing that Juvenile courts were overwhelmed with staggering amounts of cases. The courts were not able to adjudicate juvenile claims properly and effectively. Additionally, there was dissatisfaction with the sentences.)

124 Office of Juvenile Justice and Delinquency Porgram (OJJDP), Juvenile Offenders and Victims: 1999 National Report 89 (1999). Available at https://www.ncjrs.gov/html/ojjdp/nationalreport99/toc. html.

125 see OJJDP, Juvenile Justice: A Centruy of Change 1999, available at https://www.ncjrs.gov/pdffiles1/ojjdp/178995.pdf

${ }^{126}$ In re Gault, 387 U.S. 1, 1966.

127 Ibid, at 56-57.

128 Ibid., at 32. ("Notice, to comply with due process requirements, must be given sufficiently in advance of scheduled court proceedings so that reasonable opportunity to prepare will be afforded, and it must 'set forth the alleged misconduct with particularity.")

129 Ibid. at 41, ("We conclude that the Due Process Clause of the Fourteenth Amendment requires that in respect of proceedings to determine delinquency which may result in commitment to an institution in which the juvenile's freedom is curtailed, the child and his parents must be notified of the child's right to be represented by counsel retained by them, or if they are unable to afford counsel, that counsel will be appointed to represent the child.")

130 Ibid., at 55 ("We conclude that the constitutional privilege against self-incrimination is applicable in the case of juveniles as it is with respect to adults. We appreciate that special problems may arise with respect to waiver of the privilege by or on behalf of children, and that there may well be some differences in technique-but not in principle-depending upon the age of the child and the presence and competence of parents"). 
all constitutional protections to juveniles by not requiring juries in juvenile criminal proceedings. ${ }^{131}$ This preserved some of informal atmosphere that was part of the original juvenile court. ${ }^{132}$ As an addition, the case of Jackson $v$. Indiana has become the basis of limiting the duration to put inmates in incarceration that should be reasonable and based on a purpose that made the person being incarcerated. ${ }^{133}$

Generally, the minimum age of jurisdiction in the juvenile courts in the U.S. varies from six to twelve. ${ }^{134}$ North Carolina, for example, has the lowest minimum age of jurisdiction of 6 years old and maximum age of 16 years old. ${ }^{135}$ Some states even have no statutory minimum and require that every juvenile should be measured to display whether they show sufficient intellectual and emotional maturity to justify a criminal conviction. ${ }^{136}$ Other jurisdictions have an absolute age-based minimum, such as seven years of age, and discretionary jurisdiction for youths between certain ages like seven to thirteen. ${ }^{137}$ Some states put fifteen to eighteen as their maximum age. ${ }^{138}$ As happened in Indonesia, juvenile justice systems across in the US exercise jurisdiction over juvenile sex offenders and their misconduct by reference to adult penal statutes. ${ }^{139}$

\section{A. Sex Offender Laws in the United States - Facing the Same Dilemma}

Specific regulations for sex offenses are governed in the state level. Every state has different sanctions for sexual offenses. Although every state has different laws, the classifications for sex offenders are similar. Every state has classified sex offenses into tiers from the most to the less severe offenses.

In Washington State, for example, sex offense regulation is governed in the Revised Code of Washington. Sex offenses are classified into five categories: are Rape (from first to third degree), ${ }^{140}$ Rape of a Child (from first to third degree), ${ }^{141}$ Child Molestation (from first to third degree), ${ }^{142}$ Sexual Misconduct with a minor (from first to second degree), ${ }^{143}$ and voyeurism. ${ }^{144}$ The sanctions are also categorized from Misdemeanour, Gross Misdemeanour, and Felony (from class A to class C). Every category has different maximum

\footnotetext{
${ }^{131}$ McKeiver v. Pennsylvania, 403 U.S. 528, 529 (1971)

132 see OJJDP, supra note 126.

133 Jackson v. Indiana, 92 S.Ct. 1845, 715, 737 (1972) cited in Morgan v. Sproat, 432 F.Supp.1130, 1136 (S.D.Miss.1977); Morales v. Turrnan, 383 F.Supp. 53,71 (E.D.Tex. 1974; Nelson v. Heyne, 355 F.Supp.451 (N.D.Ind. 1972).

134 OJJDP, ibid.

1352011 N.C. Sess. Laws 632

136 Earl F. Martin \& Marsha Kline Pruett, The Juvenile Sex Offender and the Juvenile Justice System, 35 Am. Crim. L. Rev. 279, 316-17 (1998)

137 Ibid.

138 Ibid.

139 Ibid.

140 Wash. Rev. Code Ann § 9A.44.040 (West 1998), § 9A.44.045 (1982), § 9A.44.050 (2007), § 9A.44.060 (1999).

141 Ibid., § 9A.44.073 (1988), § 9A.44.076 (1990), § 9A.44.079 (1988).

142 Ibid., § 9A.44.083 (1994), § 9A.44.086 (1994), § 9A.44.089 (1994).

143 Ibid., § 9A.44.093 (2009), § 9A.44.096 (2009)

144 Ibid., § 9A.44.115 (2003)
} 
imprisonment range and different amount of fine. As for juveniles, the sentencing is converted based on the juvenile sentencing standards (R.C.W. 13.40.0357). Under this statutory scheme, victimizing a child would mean harsher punishment, even if the offender is also a child.

Another regulation was enacted after the congress passed the Jacob Wetterling Crimes against Children and Sexually Violent Offender Act as 42 U.S.C. § 14071, requiring states to implement a sex offender registry program..$^{145}$ This law allowed many states to impose the harsh stigmatization of registration on juveniles. In 2006, the Adam Walsh Child Protection and Safety Act of 2006 was enacted to "protect children from sexual exploitation and violent crime." ${ }^{146}$ This federal law was modelled after the Jacob Wetterling Act but contains harsher penalties for those who sexually exploit children. The Adam Walsh Act also added a central compilation of all state sex offender registries on a centralized web site maintained by the federal government. ${ }^{147}$ The list of names, along with other background information, constitutes a state sex offender registry and must be made available for viewing by the general public. ${ }^{148}$ The code does not limit registration requirement only for adult sex offenders. ${ }^{149}$ Therefore, based on this code, juveniles are also required to register. All states are required to implement this code, and states that implement will receive $10 \%$ of fund from the federal government. ${ }^{150}$

As a result, children who commit sexual offenses should also register in the community. This policy is also a reaction of certain number of harmful cases committed by juveniles. Many communities have been concerned about these programs, worrying that juveniles who committed sexual offenses in the past would re-offend and become sex offenders again as they grow up and become adults. ${ }^{151}$

At the same time, the United States' sex offender policy is also balanced with increasing number of rehabilitation facilities provided for juvenile who commit sexual offenses. As such, intervention through assessment and treatment of sexually aggressive behaviours is considered vital to both protect the community and achieve the rehabilitation goal of the juvenile justice system. ${ }^{152}$

14542 U.S.C. $§ 14071$ (a)(1)(A) (2009)

${ }^{146}$ Adam Walsh Child Protection and Safety Act of 2006, Pub. L. No. 109-248, 120 Stat. 587 (2006).

14742 U.S.C.A. $§ 16961$ (West 2006)

148 Ibid., §16914-16 (West 2006).

149 A sex offender shall register, and keep the registration current, in each jurisdiction where the offender resides, where the offender is an employee, and where the offender is a student. 42 U.S.C.A. $\S$ 16913 (West 2006)

15042 U.S.C.A. $\$ 16925$ (West 2006)

151 Serena S. Takhur, Juvenile Sex Offender: Proposition 21 - The Hope for A Better Solution, 21 J. Juv. L. 97, 101 (2000)

152 Jose I. Concepcion, Understanding Preadolescent Sexual Offenders Can These Children Be Rehabilitated to Stem the Tide of Adult Predatory Behaviours?, 2004 Fla. B.J. 30, 35-36 (2004). 


\section{B. Lessons learned from the U.S.: How the U.S. Implements Rehabilitation for Juvenile Sex Offenders}

As a part of their goal to decrease the number of sex offenses cases, the United States has provided certain treatment for juvenile sex offenders. The treatments vary based on the seriousness of the offense, the developmental level of the juvenile offender, the number of victim involved, and the relationship between the offender and the victim. ${ }^{153}$ Some treatments are held in prison, group homes, or other alternative placements, depending on whether the juvenile is at a high-risk of reoffending.

Generally, under most state juvenile justice laws, if a child is charged with sexual offense, they may be evaluated at the first stage of the case upon request of one of the parties involved. ${ }^{154}$ The evaluation will help the child at the sentencing phase. ${ }^{155}$ In some cases, the evaluation occurs during the sentencing process itself. ${ }^{156}$ The judge then will be able to make the best determination as to the appropriate disposition based on the information. ${ }^{157}$

Washington State, for example, also regulates alternative disposition for sex offenders. ${ }^{158}$ If the court finds the offender is eligible for this alternative, the court may order an examination to determine whether the respondent is amenable to treatment. ${ }^{159}$ If the examiner find that the child is amenable for treatment, a proposed treatment plan shall be provided and shall include, at a minimum: "The frequency and type of contact between the offender and therapist; specific issues to be addressed in the treatment and description of planned treatment modalities; monitoring plans, including any requirements regarding living conditions, lifestyle requirements, and monitoring by family members, legal guardians, or others; anticipated length of treatment; and recommended crime-related prohibitions." 160

After receiving the examiner's report, the court will then consider "whether the offender and the community will benefit from use of this special sex offender disposition alternative and consider the victim's opinion whether the offender should receive a treatment disposition under this section." If the court determines that this special sex offender disposition alternative is appropriate, the court will make a disposition outside the standard range in their Revised Code. ${ }^{161}$

${ }^{153}$ Victor I. Vieth, When the Child Abuser is a Child: Investigation, Prosecuting and Treating Juvenile Sex Offenders in the New Millenium, 25 Hamline L. Rev. 47, 72 (2001)

${ }^{154}$ Concepcion, supra note 153.

155 Ibid.

156 Ibid.

157 Ibid.

${ }^{158}$ Wash. Rev. Code Ann $§ 13.40 .162$ (West 2011). “(1) A juvenile offender is eligible for the special sex offender disposition alternative when: (a) The offender is found to have committed a sex offense, other than a sex offense that is also a serious violent offense as defined by RCW 9.94A.030; and (b) The offender has no history of a prior sex offense."

${ }^{159}$ Ibid., § 13.40.162. (2)(a)

160 Ibid.

161 Ibid. 


\section{Assessment}

Assessment helps providers decide which treatment will be most beneficial to the child. The assessment typically include the following information: demographics, family background, criminal history, social history, peer relationships, school adjustment and performance, drug and alcohol history, sexual behaviour and fantasy history, and history of physical or sexual abuse. ${ }^{162}$ In some cases, if the offender is amenable to treatment and the risk factor score is low, then the offender could be placed in a more open facility, rather than in a locked facility. ${ }^{163}$

In Washington State, the examination report will include: the respondent's version of the facts and the official version of the facts; offense history; assessment of problems in addition to alleged deviant behaviours; the respondent's social, educational, and employment situation; or other evaluation measures used. ${ }^{164}$

\section{Treatment}

Among treatment providers, there is a common understanding that sexual behaviour is not caused by a disease that can be cured. ${ }^{165}$ In addition, the actions do not happened spontaneously. There must be some series of events before children acts out sexually. ${ }^{166}$ Treatment exists to control the children's sexual feelings in healthy ways so that they will never commit aggressive sexual behaviour. It well helps the children to build their own control ${ }^{167}$ and there has been a significant percentage that responds favourably to therapeutic interventions. ${ }^{168}$

There are several models of treatment for sex offender. Some adopted more success than the others to juveniles commit sex offenses. Cognitivebehavioural treatment has been found to be an effective framework to address a range of psychological disorders. ${ }^{169}$ This method assumes that sexually coercive behaviour has been learned, observed, or experienced. Therefore, changing behaviour will require new ways of thinking and new responses to distressing feelings and conditions. ${ }^{170}$ This model sees that children need to learn other skills and behaviour to reduce their tendency to re-act their sexual behaviour. ${ }^{171}$

162 P. Gerardin \& F. Thibaut, Epidemiology and Treatment of Juvenile Sexual Offending, Pediatric Drugs, Vol. 6 Issue 2, 79-91 (2004)

163 Seddon \& Pass, supra note 116 , at 116.

164 Wash. Rev. Code Ann § 13.40.162 (West 2011)

165 Timothy J. Kahn, Pathways: A Guided Workbook for Youth Beginning Treatment 31 (2011).

166 Id., 111.

167 Ibid.

168 In many instances, a group treatment setting is the preferred format for treatment. In such therapy sessions, the individual is confronted by "street smart" peers who cannot be easily manipulated and who can confront the child's attempts at minimalisation and denial. Individual therapy has historically been a valuable tool but is of limited value for the sexual offender, and should not be relied upon as the sole tool. Concepcion, supra note 154 .

169 Center for Sex Offender Management (CSOM), Understanding Treatment for Adults and Juveniles Who Have Committed Sex Offenses 3, http://www.csom.org/pubs/treatment brief.pdf (Last visited June 3, 2013)

170 Vieth, supra note 155 ("The cognitive model deals with (1) a lack of empathy in the sex offender; (2) objectifitication of the victim; (3) viewing sex as something done to another person, and not something done for mutual pleasure; (4) a lack of remorse by the offender; and (5) general acceptance of violence as a part of life.")

171 Thakur, supra note 152, at 105. 
Another model that is commonly used is relapse prevention. Relapse prevention was originally designed for addictive disorders, such as substance abuse and gambling. ${ }^{172}$ Although sexual offending is not considered to be an addiction, the use of this method is also appropriate for sex offender treatment as a long-term behaviour management strategy. ${ }^{173}$ It is considered effective because the model lies on both internal and external influences. ${ }^{174}$ The internal influence comes from the juvenile himself, and the external influence comes from the family. ${ }^{175}$ This model helps offenders to control their emotion by teaching them to identify the problematic situation and then cope with it.

Another method that occurs recently is the "Good Lives Model" that requires a children with sexual behaviour problem to learn adaptive skills and develop healthy lifestyles in order to prevent re-offense. ${ }^{176}$ Other method is to utilize restorative justice throughout the treatment process that emphasizes concern for development of victim empathy, restitution, and development of personal responsibility. ${ }^{177}$ The goal of the treatment is to control a child's sexual feelings in healthy ways so that they would not do anything that could harm other person. ${ }^{178}$

Researchers have also highlighted the promise of Multisystemic Therapy (MST) with sexually abusive youth because the outcomes of juvenile sex offenders who received MST revealed much better than those who received individual therapy. ${ }^{179}$ In contrast to youth in the individual therapy, those who received MST shows fewer behaviour problems, improved family and peer relationships, better academic performance, and reduced rates of recidivism for both sexual and non-sexual crimes. ${ }^{180}$ As an addition, the family environment treatment was also that include some sort of family therapy. ${ }^{181}$ Many of the offender's beliefs and thought constructs regarding sexuality, aggression, and gender have generally developed within the home setting. ${ }^{182}$ Family therapy gives the opportunity to understand the child better and correct those distortions. ${ }^{183}$

3. Placement

Providing treatment is also depends on the availability of placement options and their appropriateness for each individual juvenile sex offender. ${ }^{184}$

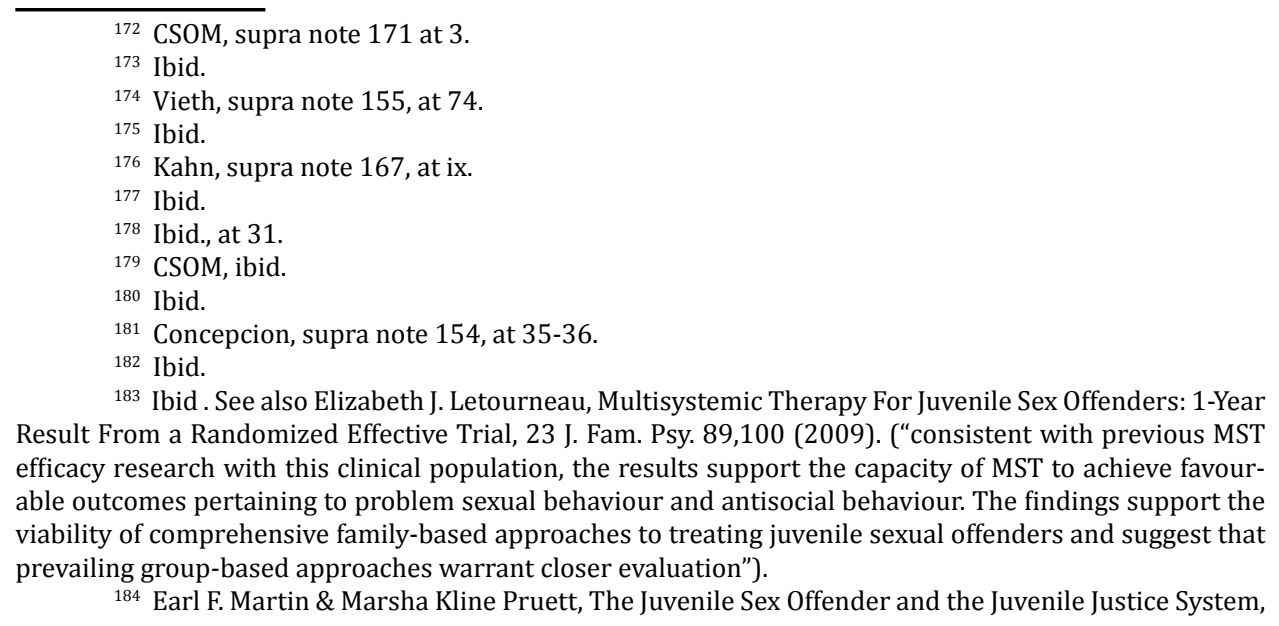


Treatment were provided in diverse settings such as schools, hospitals, mental health centers, therapy offices, and detention facilities, and options for these can range, depending how dangerous the juvenile is assessed to be, from outpatient, community-based programs, to residential settings. ${ }^{185}$

Placing children in residential treatment would be one of the ways. The children will remain in a place with certain programs. One of the benefits of residential treatment is to keep the children off of negative external influence while receiving treatment program. ${ }^{186}$ In addition, when commitment does not seem appropriate, there are resources for outpatient treatment, including private placements. ${ }^{187}$

One of the examples is group homes. It is not provided by the government, but by private entities or non-profit organizations. One of the examples of this type of group home is the Friends of Youth (FoY) in Washington State. FoY has a specialized treatment program that addresses the sexual behavioural issues of juveniles. Its programs including individualized treatment, group treatment, and also activities that connects the juveniles with the local communities. This program has a goal to prepare juvenile sex offenders in the community.

Specialized community-based treatment facilities for juvenile sex offenders are necessary because the need for the children to get used to the community. It is considered as the early therapeutic intervention in juvenile and adolescent sexually aggressive behaviour. ${ }^{188}$ Community-based treatment programs will also improve public safety by preventing further victimization. ${ }_{189}$ Finally, specialized community-based treatment, provided at the earliest recognition of the problem, costs much less than later institutional treatment for more serious sexual offenses. ${ }^{190}$

With a complete and individualized treatment plan, community-based treatment could teach juvenile offenders to accept responsibility for their offenses, control their deviant sexual urges and engage the juveniles in reeducation and reintegration. ${ }^{191}$

Furthermore, institutionalized treatment is also practiced in the US detention centre. Different than residential treatment that put children in houses; institutionalized treatment put juveniles in detention centre. One example is the treatment in the Echo Glen Children's Centre, Issaquah, Washington. This detention centre offered a uniformed treatment program such as dialectical behaviour therapy, anger replacement training, cultural programming, and inpatient chemical dependency treatment. ${ }^{192}$ Through its uniformed treatment, every resident, including children committing sexual offenses would receive the same procedure as well as individualized treatment depending on their needs.

35 Am. Crim. L. Rev. 279, 305 (1998)

185 Ibid.

186 Takhur, supra note 153, at 104.

187 Concepcion, supra note 154.

188 Rothchild, supra note 114 , at 734-35

189 Ibid.

190 Ibid.

191 Ibid.

192 Department of Social and Health Service (DSHS), http://www.dshs.wa.gov/jra/institutions. shtml\#letstalk 


\section{Strategies in Implementing Rehabilitative Approach for Juvenile Commit Sexual Offenses in Indonesia}

\section{A. Improving Research and Data Collection}

Lack of data is a common problem in Indonesia. ${ }^{193}$ Having a data is valuable to determine what the best rehabilitation system is for juvenile who commit sexual offenses, how to provide it, and whether it is effective or not. Therefore, several data should be collected in examining the need of treatment for juveniles' commit of sexual offense in Indonesia. ${ }^{194}$ The data should included number of juveniles charged with sex offenses during the past 4 years, types of the sex offenses, outcomes of the cases of those charged with sex offenses, number of juveniles that are arrested, number of juveniles that are found guilty, number of juveniles that are remain and have been released in the society, the development of juvenile sex offenders both in that are still in prison and those who are already released. Furthermore, an in-depth research should also be made that shows comprehensive analyses about the characteristic of the juvenile charged/convicted with sex offenses.

\section{B. Strategies in the Policy Level - Overcoming the Legal Barrier}

As mentioned in Section I, although there is a new law in the Indonesian juvenile justice system, there hasn't any law yet that gives a standard for judges to decide whether a juvenile needs to be imprisoned or brought to a rehabilitation institute. Furthermore, diversion can only happened for offense that has a maximum sanction of 7 years imprisonment. In this case, sex offense in Indonesian laws has a maximum of 12-15 years of imprisonment. Therefore, it will be hard for juveniles committing sexual offense to receive diversion process, except if the definition of "7 years maximum" is based on the adjusted juvenile sentencing.

Furthermore, the juvenile justice law also stated that imprisonment and institutionalization are sanctions for serious and violent crimes. In this case, sexual offense is considered as a serious and violent crime because of the impact of the victim. Based on this law, children who commit sexual offense will likely to be charged with imprisonment. ${ }^{195}$

If we look at the law as it is, the only way that a child can receive rehabilitation is if the child is under 14 years old. The law requires that children between 12 to 14 years old can only receive alternative sanction which includes rehabilitation in an institution. ${ }^{196}$ Furthermore, if the child is under 12 years old, then the process will be brought in the social system.

193 Topo Santoso, Suatu Tinjauan atas Efektivitas Pemidanaan [A Perspective of the Effectivity of Imprisonemnt], in Hukum Pidana Dalam Perspektif [Criminal Law in Perspective] 221 (Topo Santoso ed., 2012).

${ }^{194}$ Nancy G. Calley in her article "New Directions in JSO Management" has an interesting method to start data collection. This part is influenced by her paper and strategies. Nancy G. Calley, New Directions in Juvenile Sex Offender Management: Designing A Collaborative Approach, 73 DEC-Fed.Probation 50, (2009).

195 Juvenile Justice Act, art 80 (Indon.)

196 Ibid., art. 82 (1) 
A possible solution to overcome this barrier is to make a sentencing guidelines or administrative regulations. The guidelines should be regulated by the judicial body in Indonesia that will apply for all judges throughout Indonesia. By having a guideline or specific regulation, the law enforcement and the judge then can be clear in dealing with sex offense cases. The regulation should include specific adjustment in sentencing juveniles. In terms of confinement, the juvenile justice law stated that imprisonment will be applied if the child's act would harm the society ${ }^{197}$ Therefore, there is a need to require a proper assessment and examination to determine whether a child is harmful or not. This requirement should be included in the specific regulation. By having the assessment, as happened in the US' system, the chance for a juvenile to be incarcerated will be reduced. If the child were assessed as low-risk, then the judge shall charge them with rehabilitation instead of imprisonment. In fact, the Juvenile Justice Law also provide similar officer called "Pembimbing Kemasyarakatan (PK)" that are obliged to assess the condition of the juveniles and determine what is the correct sanction applied to them. ${ }^{198} \mathrm{PK}$ officers are recuited and have a social background. The result of the assessment will become one of the considerations for a judge to decide.

Furthermore, specific policy governing rehabilitation standards in all types of sanction would also be needed. Having variety of sanctions could be a challenge its own. Judges can decide variety of sanctions, thus there will be variety of decisions for similar cases. Having rehabilitation standard in all types of sanction gives every children committed of sexual offenses to receive proper treatment based on their needs.

\section{The Practice - Possible Institutions That Can Provide Rehabilitation}

By looking at the rehabilitation system in U.S., Indonesia may implement the same system within different departments. The ministry of Social Affairs can be one of the institutions that provide facilities similar to group homes. The Ministry of Social Affairs is a part of the presidential cabinet leading on programs to increase social prosperity. In fact, one of its programs is social rehabilitation for children. ${ }^{199}$ As part of its program, the ministry has what it is called as "Social Protection Homes" that can provide social services for neglected or abused children or children in need of rehabilitation services. ${ }^{200}$ Currently, the ministry has established ten homes throughout 10 provinces. ${ }^{201}$

Furthermore, the Ministry of Women and Child Protection may also promote such program with coordination with Ministry of Justice and Ministry of Social Affairs. The Ministry of Women and Child Protection is a ministry that has the obligation to promote any effort to guarantee the application of every child protection laws. Therefore, this ministry should have coordination with other two ministries to implement a comprehensive and integrated rehabilitation system.

\footnotetext{
197 Ibid., art. 81

198 Ibid., art. 65

199 Kementerian Sosial [Ministry of Social Affairs] http://www.kemsos.go.id/modules.php?name= Content $\&$ pa $=$ showpage $\&$ pid $=41$

200 Ibid.

201 Ibid.
} 
Many factors must be considered to make determination whether a child should be put in community based or any other approach. Although Indonesia has not had enough research on this, there is a necessary to put this conclusion based on the researches that is already exist in the United States. Some youth pose a greater risk than others, some have more treatment needs than others, some are more amenable to treatment than others, and some may have families that are more supportive and stable than others. ${ }^{202}$ Therefore, assessments are important to decide which treatment is applicable. As discussed above, academics can be part of this effort to determine standards for assessment.

For example, in the case of the fifth grader children, the officer should determine their family background, their deviant behaviour, and aggressiveness. If the child shows a long term deviant behaviour with lack of family support, then the children may be better served in the institutional or residential program. On the other hand, if the children show a positive behaviour and they come from a supportive and stable family environment, then the best place for them is in the community-based treatment.

\section{Considering the Victim}

One of the causes of lack of data is the number of cases that are not reported. Victims, especially minors, are unlikely to report to the law enforcement officers. One of the reasons is that the perpetrator would probably be their siblings. For juvenile sex offenders, being in prison would likely worsen their situation and did not give any rehabilitation affect. Rehabilitation system will reduce the possibility for juveniles to be labelled, and giving a better result than in the prison. This positive result would increase the number of families or victims to report the juvenile offenders because they knew that by reporting can give the juvenile offenders a chance to rehabilitate and prevent labelling from the community.

Furthermore, rehabilitation for victims will also be important. Its function is not only to reduce the victim's trauma and suffer, but also as a part of early intervention. Children who have been victimized should be offered a full-range of services to help prevent them from becoming future offenders. ${ }^{203}$ Therefore, paying the same attention to the victim will make rehabilitation easier.

\section{E. Budgeting}

Budgetary constraints are a classic problem that becomes a barrier to implement any kinds of reform in the criminal justice system. However, budget limit itself is not the only barrier. Another barrier is the perspective of the law enforcement officer that tends to treat all inmates or offenders as a criminal, thus they deserve to be treated the way they were treated now. To this extent, then, the change of perspective should also be dealt by proper

${ }^{202}$ CSOM, Juvenile Curriculum Content Treatment, http://www.csom.org/train/juvenile/4/Juvenile\%20Curriculum\%20Content\%20-\%20Treatment\%20(Topic\%204).pdf

${ }^{203}$ Seddon \& Pass, supra note 116. 
training and group discussion among legal officers.

Furthermore, in terms of budgetary limitations, there has been a lot of discussion whether rehabilitation may cause more cost rather than just bring the juvenile sex offenders into jail. One consideration that we have to think about with rehabilitation is the cost. Rehabilitation may be costly, but if we count the total of the cost, rehabilitation cost is much lower than imprisonment cost. In the U.S, the cost of sex offender rehabilitation for each juvenile is $\$ 7,000$ lower than the cost of putting the juveniles behind bars. Treatments also can reduce sexual offense recidivism by $8 \%$. This may reduce further costs.

\section{F. Human Resource}

Indonesia actually has a lot of scholars that have psychologybackgrounds. There are certain institutions that also give a concern to juveniles, such as Crisis Centre in the Faculty of Psychology University of Indonesia. They can be a potential resource to work with to build this rehabilitation system. Furthermore, special training should be held to train therapists in dealing with juvenile commit sexual offense as the juveniles would have multiple issues. Having assessment skills to decide proper treatments are also needed.

Special training for assessment skills is needed because the problems of juveniles are complicated. Even in the US, assessment has being done poorly because lack of trained therapist specialized for this type of case. ${ }^{204}$ Although this is improving, juvenile offenders are frequently assessed in the same manner as adults, using the approach that focuses very narrowly on the offense committed. ${ }^{205}$ Furthermore, specialized therapy is also needed because treating these offenders may be difficult, sometimes it will bring up significant negative emotions ${ }^{206}$ and denials. ${ }^{207}$

\section{G. The Need of Community Support}

One of the rehabilitation that is provided in the U.S. is community based treatment. But the challenge comes from the community itself. Communities are sometimes even harsher. ${ }^{208}$ Not to mention that the concept of restorative justice sometimes are misinterpreted as "forgiveness". Therefore, there is a need to have a community education to increase their awareness about the importance of rehabilitation for juvenile commit sexual offense and avoid juvenile sex offenders to be notoriously labelled by the community. Furthermore, strategies to establish community based treatment are needed.

However, the effort to raise community awareness will not be effective if we can't provide data that shows the effectiveness of rehabilitation for

${ }^{204}$ Seddon \& Pass, supra note 116.
${ }^{205}$ Ibid.
${ }^{206}$ Ibid., at115 (2004)
${ }^{207}$ Ibid.
${ }^{208}$ Ketidakpercayaan Publik Terhadap Penegak Hukum [Society's Distrust to Law Enforcement Officer], Detik.com, http://news.detik.com/read/2013/04/07/182451/2213635/10/tak-percaya-penegakhukum-warga-pilih-main-hakim-sendiri (last visited June 1, 2013) 
juvenile commit sexual offense. In the United States, changes in the juvenile justice policies usually started from "pilot projects" to demonstrate what method that works and then getting it as a suggestion for the government and for the community to support this effort. Therefore, community awareness can be increased if proper data and pilot projects has been achieved.

\section{Conclusion}

As a conclusion, juvenile sex offender rehabilitation could be an effective way to decrease the number of juveniles brought to prison in Indonesia. It may also decrease the number of unreported sex offenses, reduce the cost in juvenile justice, and promote the goal of restorative justice principle. While treating juvenile's sexual behaviour through rehabilitation will not be an easy task, it is a worth to try.

All of these rehabilitative approaches will require strong support and efforts by the Indonesian government through its policies, professional human resources, and community involvement. This rehabilitation approach will require a lot of hard work, time, and expenses for implementation. Despite some of the harsh, sex offender policies in the United States, an approach like the U.S. rehabilitation system for juveniles could help Indonesia give its offender children a second chance, to change their behaviour, to reintegrate, and to become productive members of society.

This paper recommends various strategies to achieve these goals including enhancing research on the effectiveness of rehabilitation for juveniles commit sexual offense, collaboration among departments in placing juveniles committing sexual offenses in treatment, establishing guidelines to open the access for juvenile commit sexual offences to receive treatment, and increasing the support from community and academics to contribute.

\section{Bibliography}

\section{Cases}

In re Gault, 387 U.S. 1 (1966).

McKeiver v. Pennsylvania, 403 U.S. 528, 529 (1971)

Jackson v. Indiana, 92 S.Ct. 1845 (1972)

Morales v. Turrnan, 383 F.Supp. 53 (E.D.Tex. 1974)

Morgan v. Sproat, 432 F.Supp.1130 (S.D.Miss.1977)

Nelson v. Heyne, 355 F.Supp. 451 (N.D.Ind. 1972)

\section{Legislations}

1. Republic of Indonesia

Kitab Undang-Undang Hukum Pidana 1946 [KUHP][Crim Code] (Indon.)

Kitab Undang-Undang Hukum Acara Pidana 8/1981 [Crim.Pro.Code] (Indon.).

Undang-Undang Penghapusan Kekerasan Dalam Rumah Tangga 23/2004 [Domestic

Violence Act] (Indon.) 
Undang-Undang Perlindungan Anak 23/2002 [Child Protection Act] (Indon.)

Undang-Undang Sistem Peradilan Pidana Anak 11/2012 [UU SPPA] [Juvenile Justice Act] (Indon.).

Undang-Undang Sistem Pemasyarakatan 12/1995 [Correctional System Act] (Indon.) Keputusan Presiden 36/1990 [Presidential Decision] (Indon.)

\section{United States of America}

Adam Walsh Child Protection and Safety Act of 2006, Pub. L. No. 109-248, 120 Stat. 587 (2006).

42 U.S.C. § 14071 (2009)

Wash. Rev. Code Ann § 9A.44.

2011 N.C. Sess. Laws 632

3. Other Jurisdiction

Act on Mediation in Criminal and Certain Civil Cases (Finland)

Children's Act 1998 (Ghana)

Corrections Act 2004. (New Zealand)

Crimes (Restorative Justice) Act 2004 (Canberra, Australia)

Law on Mediation. Prom. SG. 110/17 Dec 2004. (Bulgaria)

Mediation Law 22 / 2005 (Belgium)

Probation Services Amendment Act 2002. (Republic of South Africa)

Youth Criminal Justice Act -2002 (Canada)

Youth Justice and Criminal Evidence Act 1999 (UK)

\section{Convention(s)}

Convention on The Rights of The Child, G.A. Res. 44/25, U.N. GAOR, 44th Sess., Supp. No. 49, U.N.Doc A/44/25 (Nov. 20,1989)

\section{Textbooks}

Barbaree, Howard E, ed. The Juvenile Sex Offender (2006).

Becker, J.V. \& Hicks, S.J. Juvenile Sexual Offenders: Characteristics, Interventions, and Policy Issues (2003)

Eberstadt, Mary \& Layden, Mary Anne. The Social Costs of Pornography: A Statement of Findings and Recommendations (2010).

Kahn, Timothy J. Pathways: A Guided Workbook for Youth Beginning Treatment (2011).

Michael Freeman, ed. Children's Rights: A Comparative Perspective (1996)

Ministry of Women and Child Protection \& National Statistic Center (Menneg PPPA \& NSC), Profil Anak Indonesia 2011 [Profile of Children in Indonesia 2011] 78 (2011).

Pusat Kajian Perlindungan Anak (PusKaPA) [Center of Child Protection Studies (PusKaPA)], Mekanisme Pembinaan, Rehabilitasi, dan Reintegrasi Sosial bagi Anak di Indonesia [Development, Rehabilitation, and Social Reintegration Mechanism for Children in Indonesia] (2012).

Santoso, Topo, ed. Hukum Pidana Dalam Perspektif [Criminal Law in Perspective] 235 (2012). 
Snyder, Howard W. \& Sickmund, Melissa. National Center for Juvenile Justice, Juvenile Offenders and Victims: 1999 National Report (1999)

Treatment and Control Panel on Juvenile Crime, Juvenile Crime Juvenile Justice 157 (2001)

\section{Articles}

Achjani, Eva. Restorative Justice in Indonesia : Traditional Value, 2 Indon. L. Rev. 3 (2011).

Bishop, Donna M. Juvenile Offenders in the Adult Criminal Justice System, 27 Crime \& Just. 81 (2000)

Caballero, Kristin L. comment, Blended Sentencing: A Good Idea for Juvenile Sex Offenders?, 19 St. Jhon's J. 379 (2005).

Calley, Nancy G. New Directions in Juvenile Sex Offender Management: Designing A Collaborative Approach, 73 DEC-Fed.Probation 50 (2009).

Concepcion, Jose I. Understanding Preadolescent Sexual Offenders Can These Children Be Rehabilitated to Stem the Tide of Adult Predatory Behaviors?, 2004 Fla. B.J. 30 (2004).

Day, Jeffrey K. Juvenile Justice in Washington: A Punitive System in Need of Rehabilitation, 16 U. Puget Sound L. Rev. 400 (1992)

Gerardin, P. \& Thibaut, F. Epidemiology and Treatment of Juvenile Sexual Offending, Pediatric Drugs, Vol. 6 Issue 2, 79 (2004)

Jr, Hon. T. Bennett Burkemper. et.al. Restorative Justice in Missouri's Juvenile Justice, 63 J. Mo. B. 128 (2007).

Letourneau, Elizabeth J. Multisystemic Therapy For Juvenile Sex Offenders: 1-Year Result From a Randomized Effective Trial, 23 J. Fam. Psy. 89 (2009).

Martin, Earl F. \& Pruett,Marsha Kline. The Juvenile Sex Offender and the Juvenile Justice System, 35 Am. Crim. L. Rev. 279 (1998)

Ness, Daniel W. Van \& Nolan, Pat. Legislating for Restorative Justice, 10 Regent U.L.Rev. 53 (1998).

Rothchild, Sander N. Beyond Incarceration: Juvenile Sex Offender Treatment Programs Offer Youths A Second Chance, 4 J.L. \& Pol'y 719 (1996).

Seddon, Ayn Embar \& Pass, Allan D. Assessing, Managing, and Treating Juvenile Sec Offenders, 2004 J. Inst. Just. Int'l Stud. 112 (2004)

Shmueli, Benjamin. The Influence of the United Nations Convention on the Rights of the Child on Corporal Punishment - A Comparative Study, 10 Or. Rev. Int'l L. 189 (2008)

Takhur, Serena S. Juvenile Sex Offender: Proposition 21 - The Hope for A Better Solution, 21 J. Juv. L. 97 (2000)

Vieth, Victor I. When the Child Abuser is a Child: Investigation, Prosecuting and Treating Juvenile Sex Offenders in the New Millenium, 25 Hamline L. Rev. 47 (2001)

Witte, Daniel E. comment, People v. Bennett: Analytic Approaches to Recognizing a Fundamental Parental Right Under the Ninth Amendment, 1996 BYU L. Rev 186 (1996)

\section{Internet}

Center for Sex Offender Management (CSOM), Understanding Treatment for Adults and Juveniles Who Have Committed Sex Offenses 3, http://www.csom.org/ pubs/treatment brief.pdf (Last visited June 3, 2013)

Center for Sex Offender Management (CSOM), Juvenile Curriculum Content Treatment, http://www.csom.org/train/juvenile/4/Juvenile\%20Curriculum\%20 
Content\%20-\%20Treatment\%20(Topic\%204).pdf

Childs Rights International Network, Conventions on the Rights of The Child : General Comments, http://www.crin.org/docs/resources/treaties/uncrc.asp\#Nine.

Kementerian Pemberdayaan Perempuan dan Perlindungan Anak [Menneg PP\&PA] [Ministry of Women and Child Protection], Child Conflict with The Law" (2011). Available at http://menegpp.go.id/V2/index.php/datadaninformasi/ perlindungan-anak

National Center on Sexual Behavior of Youth (NCSBY), Review of Research on Adolescent Sex Offenders 1(2003), available at http://www.dshs.wa.gov/pdf/ ca/NCSBYfactsheet.pdf.

Office of Juvenile Justice and Delinquency Porgram (OJJDP), Juvenile Offenders and Victims: 1999 National Report 89 (1999). Available at https://www.ncjrs.gov/ html/ojjdp/nationalreport99/toc.html .

Office of Juvenile Justice and Delinquency Porgram (OJJDP), Juvenile Justice: A Centruy of Change 1999, available at https://www.ncjrs.gov/pdffiles1/ojjdp/178995. pdf

Olgoff, James RP, et.al. Child Sexual Abuse and Subsequent Offending and Victimisation: A 45 Year Follow-up Study (2012), available at http://www. casa.org.au/assets/ReportsPapers/Cutajar-offending-revictim-in-CSA-2012. pdf.

Reimund, Mary Ellen. The Law and Restorative Justice: Friend or Foe? A Systemic Look at the Legal Issues in Restorative Justice, 53 Drake L. Rev. 667, 671 (2005).

Retzel, Lorraine R. \& Carbonell, Joyce R. The Effectiveness of Sexual Offender Treatment for Juveniles as Measured by Recidivism: A Meta-analysis, 18 Sex Abuse 401, 413 (2006), available at http://www.wisspd.org/htm/ATPracGuides/Training/ ProgMaterials/CH980-09/ESOTJ.pdf

Riany, Yulina Eva/ Kekerasan Seksual dan Pornografi Pada Anak [Child Sexual Abuse and Pornography], Viva.co.id, http://us.analisis.news.viva.co.id/news/ read/404620-kekerasan-seksual-dan-pornografi-pada-anak (last visited April 25, 2013).

Tullis, Paul. Can Forgiveness Play a Role in Restorative Justice?, N.Y.TIMES (January 4 , 2013) available at http://www.nytimes.com/2013/01/06/magazine/ can-forgiveness-play-a-role-in-criminal-justice.html?pagewanted $=1 \&_{-}$ $r=3 \&$ comments.

Bocah SD Pemerkosa Dipindahkan ke Dinsos Makassar [Elementary School Boys were Brought to Sosial Institution Makassar], LiputanChampions.com, http:// www.liputanchampions.com/video/1129644/5-bocah-sd-pemerkosadipindahkan-ke-dinsos-makassar (last visited April 23, 2013).

Department of Social and Health Service (DSHS), http://www.dshs.wa.gov/jra/ institutions.shtml\#letstalk

Geng Anak Pemerkosa [Child Rape Gangs], Republika.co.id, http://www.republika. co.id/berita/nasional/jabodetabek-nasional/13/04/07/mkviiv-kriminologgeng-anak-pemerkosa-karena-pornografi (last visited April 23, 2013).

Indonesia Gets Failing Grade Juvenile Justice System, TheJakartaPost.com, http:// www.thejakartapost.com/news/2007/07/28/indonesia-gets-failing-gradejuvenile-justice-system.html (last visited May 29th, 2013).

Kementerian Sosial [Ministry of Social Affairs] http://www.kemsos.go.id/modules.ph $\mathrm{p}$ ?name $=$ Content $\& \mathrm{pa}=$ showpage $\& \mathrm{pid}=41$

Ketidakpercayaan Publik Terhadap Penegak Hukum [Society's Distrust to Law Enforcement Officer], Detik.com, http://news.detik.com/read/2013/04/07/1 
82451/2213635/10/tak-percaya-penegak-hukum-warga-pilih-main-hakimsendiri (last visited June 1, 2013)

KPAI: Pemerkosaan dan Moralitas [KPAI : Rape and Morality], Kompas.com, http://megapolitankompas. com/read/2013/03/18/15035990/KPAI.Pelaku.Pemerkosaan.Bergilir.Biadab.dan.Tidak. Bermoral (last visited May 21, 2013).

Perkosaan Kakak-Adik [Sibling Rapes], SindoNews.com, http://daerah.sindonews. $\mathrm{com} / \mathrm{read} / 2012 / 10 / 19 / 25 / 681193 /$ sering-nonton-video-porno-kakakperkosa-adik (last visited April 23, 2013). 